\section{Stimulation of Germination and Seedling Vigor in Dormant Seeds of African Juniper}

\author{
Yasser Ismail El-Nashar ${ }^{1,2}$ and Yaser Hassan Dewir ${ }^{1,3}$
}

ADDITIONAL INDEX WORDs. dormancy breaking, Juniperus procera, seedling growth, seedling morphology, vigor indices

SUMMARY. Breaking of dormancy in african juniper (Juniperus procera) seeds is a challenge faced by nurseries attempting to grow large numbers of this plant for restoration projects. The purpose of this study was to develop a protocol for breaking dormancy and stimulating germination in african juniper. Seeds were presoaked in different concentrations $\left(0,1,10\right.$, or $\left.20 \mathrm{mg} \cdot \mathrm{L}^{-1}\right)$ of gibberellic acid $\left(\mathrm{GA}_{3}\right)$, indole-3-butyric acid (IBA), and naphthalene acetic acid (NAA), and incubated under different air temperatures $\left(10,15\right.$, and $\left.20^{\circ} \mathrm{C}\right)$. The petri dishes were monitored daily for 84 days, to record germination percentage, rate, and uniformity, and the growth of shoots and roots, and biomass production. The highest germination percentages were obtained under $20{ }^{\circ} \mathrm{C}$ with a high concentration of NAA $\left(20 \mathrm{mg} \cdot \mathrm{L}^{-1}\right)$. The greatest seedling growth was under $20{ }^{\circ} \mathrm{C}$ with IBA. The greatest seedling length was under $20^{\circ} \mathrm{C}$ with a low concentration of IBA (1 $\left.\mathrm{mg} \cdot \mathrm{L}^{-1}\right)$. The greatest shoot fresh weight was under $20{ }^{\circ} \mathrm{C}$ with medium $\mathrm{GA}$ concentration $\left(1 \mathrm{mg} \cdot \mathrm{L}^{-1}\right)$. Compared with the control, almost all growth regulator treatments stimulated higher germination percentages and vigor indices with increased temperatures.

$\mathrm{G}$ ermination is a critical event in the life cycle of a plant, and its timing largely predetermines seedling survival (Chauhan et al., 2010). Both morphologically and physiologically, dormancy must be broken for germination to occur. Even under optimal conditions (e.g., temperature, light, oxygen, and moisture), some seeds do not germinate due to seed dormancy (Bewley et al., 2013; Poljak et al., 2015). Seed dormancy takes five different forms, namely morpho-physiological dormancy, morphological dormancy, physiological dormancy, physical dormancy, and a combination of physical

Received for publication 8 July 2019. Accepted for publication 22 Aug. 2019.

Published online 2 October 2019.

${ }^{1}$ Plant Production Department, P.O. Box 2460, College of Food and Agriculture Sciences, King Saud University, Riyadh 11451, Saudi Arabia

${ }^{2}$ Ornamental Plants and Landscape Gardening Research Department, Horticultural Research Institute, A.R.C., Alexandria 21554, Egypt

${ }^{3}$ Department of Horticulture, Faculty of Agriculture, Kafrelsheikh University, Kafr El-Sheikh 33516, Egypt

The authors extend their appreciation to the Deanship of Scientific Research at King Saud University for funding this work through research group no. RG-1438-012, and the Researchers Support \& Services Unit for their technical support.

Y.H.D. is the corresponding author. E-mail: ydewir@ hotmail.com or ydewir@ksu.edu.sa.

This is an open access article distributed under the CC BY-NC-ND license (https://creativecommons.org/ licenses/by-nc-nd/4.0/).

https://doi.org/10.21273/HORTTECH04452-19 and physiological dormancy (Baskin and Baskin, 2004, 2014; Bonner, 2008). Seeds of juniper (Juniperus) species possess various dormancy characteristics, such as physiological dormancy in phoenicean juniper (J. phoenicea) or morphophysiological dormancy in persian juniper (J.polycarpos), which make sexual propagation difficult (Al-Ramamneh et al., 2012; Daneshvar et al., 2016). Under natural conditions, juniper seeds typically take 2 years or more to germinate, and low percentages and rates of germination are common. These problems result from a combination of chemical factors in the embryo, and physical factors, such as the thick, solid outer layer of the two-layered seedcoat (Bassett, 1987; Tilki, 2007; Tylkowski, 2009, 2010). Dealy (1990) indicated that the germination of many juniper species is delayed by embryo dormancy or solid seedcoats. Many plant species have evolved dormancy as a means of optimally timing germination to $\mathrm{CO}^{-}$ incide with conditions favorable for the growth and survival of the next generation (Leadem, 1997).

Temperature is an important factor influencing germination, and species survival. Temperature requirements of seeds from different populations of a species can vary, and the germination requirements of plants depend on interactions between genes and the environment, and on species-specific seed dormancy patterns (Baskin and Baskin, 2001; Nikolaeva, 1977). Seed germination also is affected by growth regulators and enzymatic activity. Evidence for the participation of growth regulators in seed germination comes from the correlation between hormone concentrations and specific development stages, effects of hormone treatments, and the relationship of hormones with metabolic activities. Occasionally, growth and/or differentiation are inhibited by hormones. This inhibition can be alleviated by treatment with growth regulators such as auxins and gibberellins (Chauhan et al., 2009).

The present study was conducted to examine 1) the efficacy of different temperatures in breaking dormancy; 2 ) the effects of applied plant growth regulators (PGRs), NAA, $\mathrm{GA}_{3}$, and IBA, under different concentrations on dormancy release; and 3) whether dormancy release and germination of african juniper seeds are stimulated by applications involving a combination of temperature and PGRs.

\section{Materials and methods}

SeEd COLlection, SURFACE STERILIZATION, AND GERMINATION TREATMENTS. At the end of Aug. 2017, ripe cones were collected from african juniper trees grown in the Riyadh Reserve, which is located in southwestern Saudi Arabia. Seeds were collected from 15 randomly selected trees from a natural $75-\mathrm{m}^{2}$ stand. Seeds were extracted from the cones by soaking cones in a solution of $\mathrm{l} \mathrm{g} \cdot \mathrm{L}^{-1}$ sodium hydroxide $(\mathrm{NaOH})$ with warm water for $2 \mathrm{~d}$ to soften the outer

\begin{tabular}{llll}
\hline $\begin{array}{l}\text { Units } \\
\text { To convert U.S. to SI, } \\
\text { multiply by }\end{array}$ & U.S. unit & SI unit & $\begin{array}{l}\text { To convert SI to U.S., } \\
\text { multiply by }\end{array}$ \\
\hline 0.0929 & $\mathrm{ft}^{2}$ & $\mathrm{~m}^{2}$ & 10.7639 \\
2.54 & inch $(\mathrm{es})$ & $\mathrm{cm}$ & 0.3937 \\
28.3495 & $\mathrm{oz}$ & $\mathrm{g}$ & 0.0353 \\
7.4892 & $\mathrm{Oz} / \mathrm{gal}$ & $\mathrm{g} \cdot \mathrm{L}^{-1}$ & 0.1335 \\
1 & $\mathrm{ppm}$ & $\mathrm{mg} \cdot \mathrm{L}^{-1}$ & 1 \\
$\left({ }^{\circ} \mathrm{F}-32\right) \div 1.8$ & ${ }^{\circ} \mathrm{F}$ & ${ }^{\circ} \mathrm{C}$ & $\left({ }^{\circ} \mathrm{C} \times 1.8\right)+32$
\end{tabular}


coating. Cones were rinsed with warm water. To separate the seeds from the pulp, seeds were rubbed on a screen. Seeds were air dried (Harrington, 1977). Moisture content of the seeds was $12 \%$ tol $5 \%$. After pre-washing the seeds with tap water for $1 \mathrm{~h}$, they were surface sterilized in a laminar flow cabinet, by soaking them in $70 \%$ ethanol for $2 \mathrm{~min}$ and $1 \%$ sodium hypochlorite for $10 \mathrm{~min}$. The seeds were rinsed three times ( $15 \mathrm{~min}$ each) with distilled water. The seeds were presoaked for $24 \mathrm{~h}$ at various concentrations $(0,1,10$, or 20 $\left.\mathrm{mg} \cdot \mathrm{L}^{-1}\right)$ of PGR $\left(\mathrm{GA}_{3}, \mathrm{IBA}\right.$, or NAA) (Caisson Laboratories, Smithfield, UT) at various temperatures $(10,15$, and $20{ }^{\circ} \mathrm{C}$ ). Seeds soaked in distilled water served as a control. The seeds were placed in petri dishes (ExtraGene, Taichung City, Taiwan) with wet filter paper (Whatman International, Maidstone, UK) and incubated in a seed germinator (KB 240-UL; Binder, Tuttlingen, Germany) under a 16-h photoperiod provided by cool white fluorescent tubes and a light intensity of $34 \mu \mathrm{mol} \cdot \mathrm{m}^{-2} \cdot \mathrm{s}^{-1}$ photosynthetic photon flux density. On daily monitoring, the mean germination percentages, growth of root and shoots, and increases in biomass were measured.

EXPERIMENTAL DESIGN AND STATISTICAL ANALYSIS. The experimental layout was a split-split-plot in a complete randomized block design, with three replicates per treatment (Steel and Torrie, 1986). The three PGR treatments $\left(\mathrm{GA}_{3}, \mathrm{IBA}\right.$, and NAA) were arranged in the subplots, and the four concentration treatments $(0,1,10$, and $\left.20 \mathrm{mg} \cdot \mathrm{L}^{-1}\right)$ were randomly allocated to the sub-subplots. Each plot had three petri dishes in each replicate. For the seed germination test, 20 seeds were planted in petri dishes on moistened filter paper. Regression analysis, analysis of variance, and comparison of correlation coefficients were conducted using SAS (version 9.2; SAS Institute, Cary, NC) software, and the means of the different treatments were compared using the least significant difference test at the 5\% probability levels.

Data collection. Seed germination was measured daily with a final count after $84 \mathrm{~d}$. The shoot dry weights (SDW) and entire seedlings were measured after oven-drying the seedlings at $80{ }^{\circ} \mathrm{C}$ for $48 \mathrm{~h}$. Ten seedlings were randomly selected from petri dishes and seedling length, and the lengths of shoots (SL) were measured, in addition to shoot fresh weight (SFW).

To evaluate germination time and speed, and to calculate seed vigor, petri dishes were checked daily, and the number of germinated seeds was recorded. Mean time to germination (MTG) is an index of seed germination speed and velocity (Ellis and Roberts, 1981) and is calculated as follows:

$$
M T G=\neg \neg \neg \frac{\sum(n i \times d i)}{\sum_{n i}},
$$

where $n_{i}$ is number of seeds newly germinated at time $\mathrm{d}, d_{i}$ is the days from beginning of the germination test, and $\sum_{n i}$ is the final number of germinated seeds.

Mean daily germination (MDG) is an index of daily germination speed and is calculated as follows:

$$
M D G=\frac{F G P}{T p},
$$

where $F G P$ is the final germination percentage and $T p$ is the test period.

Germination speed was calculated using the following formula (International Seed Testing Association, 1999):

$$
\begin{aligned}
\text { Germination rate } & =\frac{\text { No. normal seedlings }}{\text { days to first count }} \\
& +\ldots+\frac{\text { No. normal seedlings }}{\text { days to final count }}
\end{aligned}
$$

Seedling weight and length vigor indices (SWVI and SLVI, respectively) were determined using the following formulae (Ashkan and Jalal, 2013):

$$
\begin{aligned}
& \text { SLVI }=(\text { mean shoot length } \\
& + \text { mean root length }) \times F G P
\end{aligned}
$$

$S W V I=$ mean seedling weight $\times F G P$

\section{Results}

The results showed significant differences among temperature (main plots), growth regulator type (subplots), and growth regulator concentrations (sub-subplots), as well as their interaction across all studied parameters (Table 1).

Germination RESPONSES TO TEMPERATURE. The germination percentages were significantly greater for seeds incubated at a higher temperature $\left(20^{\circ} \mathrm{C}\right)$ and significantly lower for seeds incubated at a lower temperature $\left(10{ }^{\circ} \mathrm{C}\right)$. Increase in temperature to $20{ }^{\circ} \mathrm{C}$ resulted in an increase in germination rate, vegetative growth, MDG, SLVI, and SWVI. On the other hand, the MTG was reduced (Table 1).

Germination RESPONSES TO PGR TYPE AND CONCENTRATIONS. PGR type and their concentrations significantly increased germination and growth of african juniper seeds, as compared with the control treatment. Except for SFW and SDW, all other parameters were significantly influenced by PGR type and their concentrations (Table 1). All PGR concentrations significantly enhanced the seed germination when compared with the control group, and for all incubation temperatures (Table 1). Among the PGRs tested, NAA showed overall higher seed germination (SG) as compared with IBA or $\mathrm{GA}_{3}$. However, the highest seedling SL was observed with IBA.

Germination Responses to COMBINATIONS OF TEMPERATURES AND PGRs. The maximum SG was observed in NAA-treated seeds at $20{ }^{\circ} \mathrm{C}$, and $\mathrm{SG}$ of seeds soaked in $\mathrm{NAA}$, IBA, and $\mathrm{GA}_{3}$ were $83.89 \%$, $75.56 \%$, and $73.33 \%$, respectively, whereas that in water was $66.67 \%$ at the end of the $84-\mathrm{d}$ incubation period at $20^{\circ} \mathrm{C}$. The control at $10{ }^{\circ} \mathrm{C}$ showed the lowest germination (15.01\%). Germination improved with increasing temperature for all three PGRs. For seedling vigor parameters, such as MDG and vigor index values, treatment with NAA at $20{ }^{\circ} \mathrm{C}$ produced maximum values (Table 1 ).

Germination Responses to COMBINATIONS OF TEMPERATURES AND PGR CONCENTRATIONS AND COMBINATIONS OF PGR TYPE AND PGR CONCENTRATIONS. Germination improved with temperature for all PGR concentrations. Significant interaction effects were detected in seedling SL, SFW, and root fresh weight (RFW) between PGR type and PGR concentration. The interaction effects among PGR type and concentration of PGR on MTG, MDG, SLVI, and SWVI were significant (Table 1). Middle range concentrations of IBA and high concentrations of NAA produced large seedling SLs of 6.03 and $3.00 \mathrm{~cm}$, respectively. Application of $10 \mathrm{mg} \cdot \mathrm{L}^{-1} \mathrm{IBA}$ and 20 $\mathrm{mg} \cdot \mathrm{L}^{-1} \mathrm{GA}_{3}$ stimulated elongation in seedling SL $6.03 \mathrm{~cm}$, whereas application of 20 ppm NAA also increased weight $(0.039 \mathrm{~g})$ compared with the other treatments (Table 1 ). 
Table 1. Seed germination (SG), seedling length (SL), shoot fresh weight (SFW), shoot dry weight (SDW), mean time to germination (MTG), mean daily germination (MDG), seedling length vigor index (SLVI), and seedling weight vigor index (SWVI) of african juniper in different temperatures and plant growth regulator (PGR) types and concentrations.

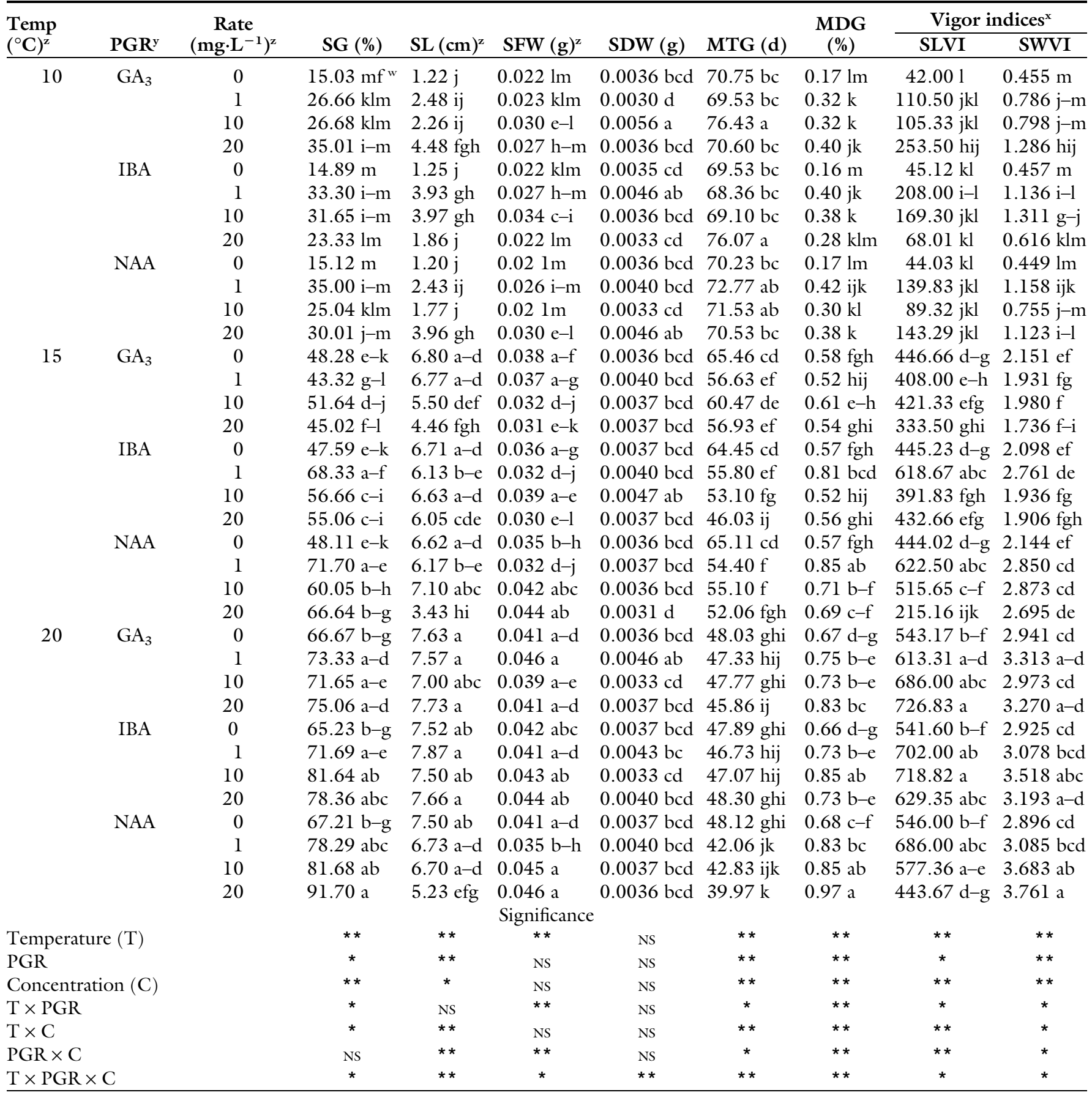

${ }^{2}\left({ }^{\circ} \mathrm{C} \times 1.8\right)+32={ }^{\circ} \mathrm{F}, 1 \mathrm{mg} \cdot \mathrm{L}^{-1}=1 \mathrm{ppm}, 1 \mathrm{~cm}=0.3937$ inch, $1 \mathrm{~g}=0.0353 \mathrm{oz}$.

${ }^{y} \mathrm{GA}_{3}=$ gibberellic acid, $\mathrm{IBA}=$ indole-3-butyric acid, $\mathrm{NAA}=$ naphthalene acetic acid.

${ }^{\mathrm{X}} \mathrm{SLVI}=($ mean shoot length + mean root length $) \times$ FGP, SWVI $=$ mean seedling weight $\times$ FGP (Ashkan and Jalal, 2013).

"Means followed by similar letters in each column are not significantly different at $P \leq 0.05$ level, according to least significant difference test. Ns, ${ }^{*}$ Nonsignificant or significant at $P \leq 0.05$, respectively.

INTERACTION EFFECTS OF TEMPERATURe, PGR TYPe, AND PGR CONCENTRATIONS. The highest percentage of germination $(91.70 \%)$ was recorded for seeds incubated at $20^{\circ} \mathrm{C}$, treated with $20 \mathrm{mg} \cdot \mathrm{L}^{-1} \mathrm{NAA}$, followed by those incubated at $20^{\circ} \mathrm{C}$, treated with $10 \mathrm{mg} \cdot \mathrm{L}^{-1} \mathrm{NAA}(81.68 \%)$ and those incubated at $20^{\circ} \mathrm{C}$, treated with $10 \mathrm{mg} \cdot \mathrm{L}^{-1}$ IBA (81.64\%). The lowest germination percentages, of $14.89 \%$ and $15.03 \%$, were observed for seeds incubated at $10{ }^{\circ} \mathrm{C}$ with control treatments of IBA and $\mathrm{GA}_{3}$, respectively (Table 1). The greatest shoot elongation $(7.87 \mathrm{~cm})$ was observed for seeds incubated at $20^{\circ} \mathrm{C}$ with $1 \mathrm{mg} \cdot \mathrm{L}^{-1} \mathrm{IBA}$, and the lowest elongation values (1.22, 1.25 , and $1.20 \mathrm{~cm}$ ) were observed for the control group under a low temperature of $10{ }^{\circ} \mathrm{C}$.

Regarding biomass, the greatest SFW $(0.046 \mathrm{~g})$ was recorded for seeds incubated under a high temperature 
of $20^{\circ} \mathrm{C}$ with either $\mathrm{l} \mathrm{mg} \cdot \mathrm{L}^{-1} \mathrm{GA}_{3}$ or $20 \mathrm{mg} \cdot \mathrm{L}^{-1} \mathrm{NAA}$, followed by the SFW for seeds incubated at $20^{\circ} \mathrm{C}$ with 10 $\mathrm{mg} \cdot \mathrm{L}^{-1} \mathrm{NAA}(0.045 \mathrm{~g})$; the lowest SFW $(0.02 \mathrm{l}-0.022 \mathrm{~g})$ was recorded for the control group incubated under a low temperature of $10^{\circ} \mathrm{C}$ (Table 1). The greatest SDW $(0.0056 \mathrm{~g})$ was recorded for seeds incubated at $10{ }^{\circ} \mathrm{C}$ with $10 \mathrm{mg} \cdot \mathrm{L}^{-1} \mathrm{GA}_{3}$, and the lowest SDW was recorded for seeds incubated under a low temperature of $10{ }^{\circ} \mathrm{C}$ with $1 \mathrm{mg} \cdot \mathrm{L}^{-1} \mathrm{GA}_{3}$.

The SFW, MDG, and seedling vigor index (SVI) increased as temperature increased, particularly at the highest concentration $\left(20 \mathrm{mg} \cdot \mathrm{L}^{-1}\right)$ of $\mathrm{NAA}, \mathrm{IBA}$, and $\mathrm{GA}_{3}$, compared with the control group. The SVI of the control group at $10{ }^{\circ} \mathrm{C}$ were the lowest observed, whereas the greatest SLVI was observed for seeds incubated at $20{ }^{\circ} \mathrm{C}$ with $20 \mathrm{mg} \cdot \mathrm{L}^{-1} \mathrm{GA}_{3}$ (726.83), and the greatest SWVI was observed for seeds incubated at $20^{\circ} \mathrm{C}$ with $20 \mathrm{mg} \cdot \mathrm{L}^{-1} \mathrm{NAA}(3.761)$. MTG decreased when the temperature was increased from 10 to $20^{\circ} \mathrm{C}$, and the greatest MTG was observed for the seeds incubated at $10{ }^{\circ} \mathrm{C}$ with 10 $\mathrm{mg} \cdot \mathrm{L}^{-1} \mathrm{GA}_{3}$ (76.43) (Table 1).

Time Change IN Germination PERCENTAGE. Our results on germination percentages over the $84 \mathrm{~d}$ of observation showed the following: at $10{ }^{\circ} \mathrm{C}$ and $20 \mathrm{mg} \cdot \mathrm{L}^{-1}$ germination (35.01\%) occurred only for $\mathrm{GA}_{3}$. However, NAA and IBA at concentrations of $\mathrm{l} \mathrm{mg} \cdot \mathrm{L}^{-1}$ at $10{ }^{\circ} \mathrm{C}$ gave germination rates of $35 \%$ and $33.30 \%$, respectively (Fig. 1A-C). At $15^{\circ} \mathrm{C}$ and $10 \mathrm{mg} \cdot \mathrm{L}^{-1}$ a germination of $51.64 \%$ was obtained with $\mathrm{GA}_{3}$. SG also occurs with NAA and IBA $\left(1 \mathrm{mg} \cdot \mathrm{L}^{-1}\right)$ treatments of $71.70 \%$ and $68.33 \%$, respectively (Fig. 1D-F). The greatest seed germination was observed for the seeds incubated at $20{ }^{\circ} \mathrm{C}$ with $20 \mathrm{mg} \cdot \mathrm{L}^{-1}$ $\mathrm{GA}_{3}$ and NAA $(75.06 \%$ and $91.70 \%$, respectively), and SGs of $81.64 \%$ and $81.68 \%$, respectively, for $20^{\circ} \mathrm{C}$ with 10 $\mathrm{mg} \cdot \mathrm{L}^{-1}$ IBA and NAA were also obtained (Fig. 1G-I).

\section{Discussion}

Physical seedcoat dormancy happens in junipers (Schmidt, 2000). Fordham and Spraker (1977) reported that juniper seeds are prohibited from germinating by impervious seedcoats that delay the admission of water, in addition to undeveloped embryos. Seeds are said to be doubly dormant, because two circumstances must be overwhelmed before germination can take place. In wildlife, these seeds require 2 years or more to germinate. Slow and low germination percentages, with germination from time to time being delayed more than 2 years in juniper, are not uncommon. These issues result from a combination of chemical factors in the physical and embryo factors, such as the thick solid outer layer of the two-layered seedcoat (Bassett, 1987; Djavanshir and Fechner, 1976). Broome (2003) specified that juniper trees can be difficult to propagate from seed because they are slow growing and vulnerable to browsing.

Our study investigated the influences of three different PGRs and temperatures on the morphology and germination of african juniper seeds, including comparison of vigor of seedlings. Temperature affects both germination percentage and speed by influencing water uptake, thereby influencing the physiological processes and biochemical reactions that determine germination (Oliveira et al., 2013; Taiz and Zeiger, 2010). Several investigators have noted that germination percentage improved with increase in temperature (Baskin and Baskin, 2004; Gimenez et al., 2005; Labbafi et al., 2018). It is well known that temperature still plays a very important role in the germination of seeds for many plant species because temperature is an environmental signal. Temperature influences both germination ability and the rate at which germination occurs (Bewley and Black, 1994).

Our results under low and medium temperatures are similar to those of Bewley and Black (1994). The embryos of juniper seeds are morphologically immature and require a period of additional growth before they are able to germinate. However, in some plant species with morphologically immature embryos, the developmental period is followed by a period of embryo dormancy, which is ended by low temperature. The hydrated seeds of many woody and herbaceous species are released from dormancy when exposed to temperatures of 5 to $15^{\circ} \mathrm{C}$. Plant species respond differently to the most effective temperatures range (Brandel and Schutz, 2003). On the other hand, Baskin and Baskin (2004) and Daneshvar et al. (2016) indicated that cold stratification at $1^{\circ} \mathrm{C}$ up to 16 weeks was not effective to completely break dormancy of juniper seeds, and that application of $\mathrm{GA}_{3}$ was more effective at releasing dormancy than a combined treatment of cold stratification and PGR. Morpho-physiological dormancy is the most common dormancy type in juniper seeds. Seeds may have simple morpho-physiological dormancy, which might be an adaptive instrument for comparatively warmer autumn temperature throughout seed maturation and the following cold winter temperature under natural circumstances. Yavuz and Yilmaz (2017) reported that the highest germination percentage of syrian juniper $(J$. drupacea) seeds was obtained after warm and cold stratifications. Moreover, seeds prechilled for 8 weeks and soaked in $500 \mathrm{ppm} \mathrm{GA} 3$ also demonstrated high germination percentages. However, $\mathrm{GA}_{3}$ without any pretreatments did not have a significant effect on the germination of syrian juniper seeds, indicating that juniper seeds have morpho-physiological dormancy. Due to seed lot variability, germination percentages and dormancy behavior can also be traced to environmental and genetic effects during seed growth (Daneshvar et al., 2016; Mazer and Lowry, 2003). We are aware that african juniper seeds we used were collected from randomly selected trees in a natural area, and that natural variation may have accounted for some of the differences we observed in germination and dormancy behavior. However, temperature was an important influence on dormancy release. Although dormancy release generally occurs in the region of $5^{\circ} \mathrm{C}$, in some cases it may occur between 12 and $15{ }^{\circ} \mathrm{C}$ (Baskin and Baskin, 2001).

By stimulating enzyme activity, seed hormones improve and promote seed vigor and germination (Ding, 2004; Fan et al., 2012). Auxin has been reported to promote cell division and SG, initiate growth of dormant buds, and promote development of lateral roots (Boerjan et al., 1995; Muday and Haworth, 1994). Jiang and Chen (1997) reported that vigor index, germination rate, and catalase and peroxidase activity could be enhanced by soaking the seeds in a sufficiently concentrated solution of NAA. Song et al. (2009) reported that meeting the environmental requirements of seeds by pretreating them 

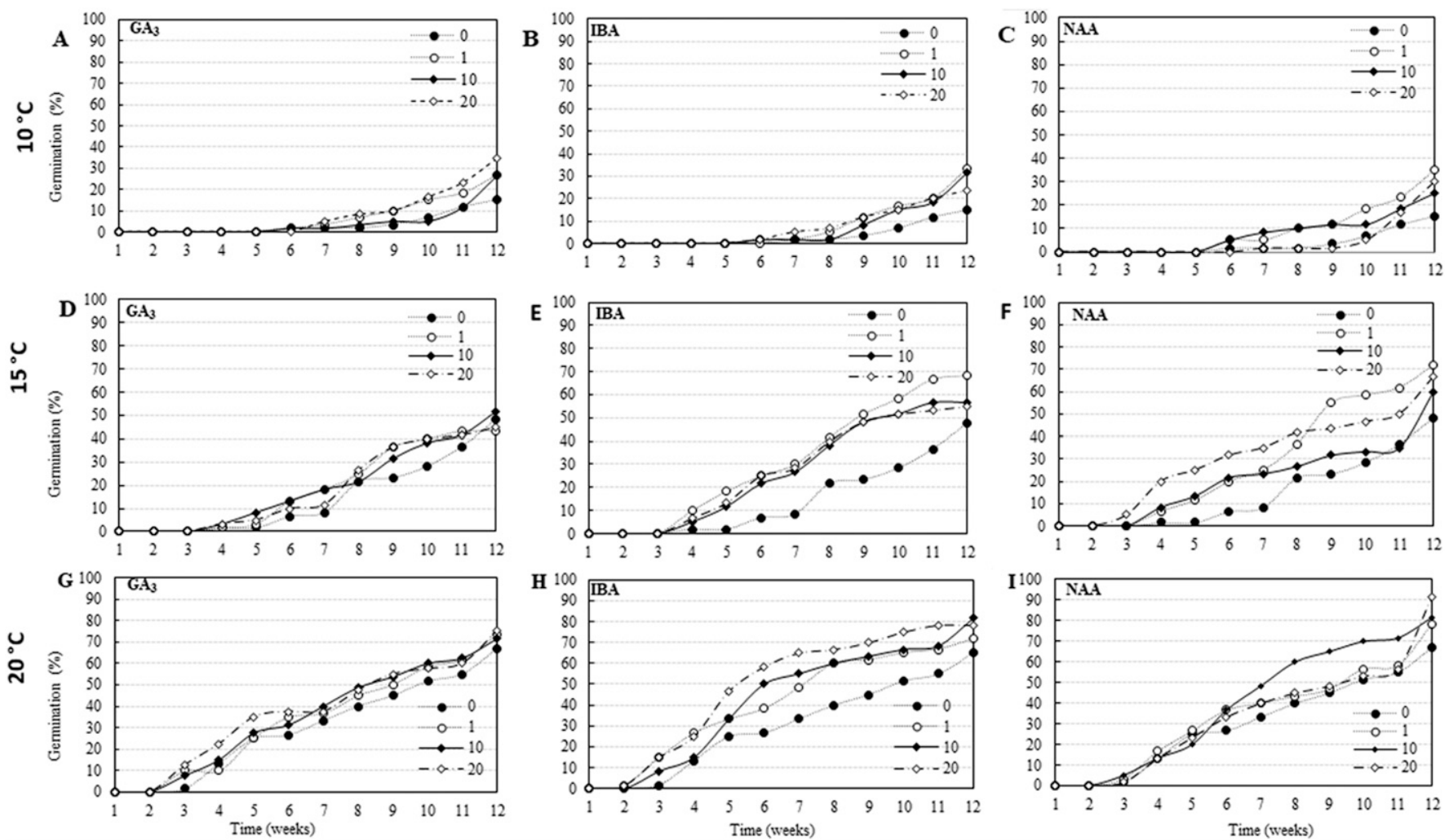

Fig. 1. (A-I) Time-course changes in germination percentage for african juniper seeds in different temperature (10, 15, and $20^{\circ} \mathrm{C}$ ) treatments and plant growth regulators [gibberellic acid $\left(\mathrm{GA}_{3}\right)$, indole-3-butyric acid (IBA), naphthalene acetic acid (NAA) $]$ and their concentrations $\left(0,1,10\right.$, and $\left.20 \mathrm{mg} \cdot \mathrm{L}^{-1}\right) ; 1 \mathrm{mg} \cdot \mathrm{L}^{-1}=1 \mathrm{ppm},\left({ }^{\circ} \mathrm{C} \times 1.8\right)+32={ }^{\circ} \mathrm{F}$.

with different PGRs promoted the germination of crape myrtle (Lagerstoemia subcostata).

The role of PGR in breaking dormancy of tree seeds is wellknown (Daneshvar, et al., 2016). The applications of $\mathrm{GA}_{3}$ have been typically used to break physiological dormancy of solid seedcoat species (Daneshvar, et al., 2016; Yao et al., 2015). An interesting feature of our trial was the effectiveness of $\mathrm{GA}_{3}$ in enhancing $S G$, irrespective of temperature. The treatment of seeds with high temperature and NAA appears to increase germination. The role of PGR in overcoming the harmful effects on growth may be due to the change in endogenous growth substances that they initiate (Hoque and Haque, 2002; Yoshida and Hirasawa, 1996). Although SG, and root and shoot elongation varied in response to different treatments, presoaking the seeds in PGR clearly improved germination and seedling establishment, as previously reported by Ahmad et al. (1998) and Harris et al. (1999). Penfield (2017) reported that $\mathrm{GA}_{3}$ is the most extensively used PGR for improving SG percentage in different plant species. The 24-h soaking period increased total water uptake, which likely increased the imbibition rate, initiating the biochemical changes required for SG.

\section{Conclusions}

In an effort to break dormancy and stimulate germination of african juniper seeds, we tested the effects of different, combined temperature and hormone treatments. We drew the following conclusions from our results: 1) an increased temperature of $20^{\circ} \mathrm{C}$ up to 12 weeks is effective to break dormancy; 2) exogenous applications of NAA, IBA, and $\mathrm{GA}_{3}$ play a minor role in dormancy release compared with the control, but combined treatments are effective in breaking dormancy; 3 ) incubating african juniper seeds at $20{ }^{\circ} \mathrm{C}$ with $20 \mathrm{mg} \cdot \mathrm{L}^{-1} \mathrm{NAA}$ at 12 weeks induces germination of $91.70 \%$, and is a simple, economically viable alternative to the application of costly plant growth substances; and 4) the study suggests that morpho-physiological dormancy is the most probable dormancy type in african juniper seeds.
This mode of dormancy may be an adaptation to arid environments, and african juniper's rapid seedling growth makes it a useful species for desert reclamation and the sustainable development of arid zones.

\section{Literature cited}

Ahmad, S., M. Anwar, and H. Ullah. 1998. Wheat seed pre-soaking for improved germination. J. Agron. Crop Sci. 181:125-127.

Al-Ramamneh, E.A., S. Dura, and N. Daradkeh. 2012. Propagation physiology of Juniperus phoenicea L. from Jordan using seeds and in vitro culture techniques: Baseline information for a conservation perspective. Afr. J. Biotechnol. 11:7684-7692.

Ashkan, A. and M. Jalal. 2013. Effect of salinity on seed germination and seedling vigor indices of two halophytic plant species (Agropyron elongatum and $A$. pectiniforme). Intl. J. Agr. Crop Sci. 5:2669-2676.

Baskin, C.C. and J.M. Baskin. 2001. Seeds: Ecology, biogeography, and evolution of dormancy and germination. Academic Press, San Diego, CA. 
Baskin, C.C. and J.M. Baskin. 2014. Seeds: Ecology, biogeography, and evolution of dormancy and germination. 2nd ed. Elsevier/Academic Press, San Diego, CA.

Baskin, J.M. and C.C. Baskin. 2004. A classification system for seed dormancy. Seed Sci. Res. 14:1-16.

Bassett, R.L. 1987. Silviculture systems for pinyon-juniper. Proc. Pinyon- Juniper Conf. Reno, NV. 13-16 Jan. 1986. U.S. Dept. Agr., For. Serv., Gen. Tech. Rpt. INT-215. p. 273-278.

Bewley, J.D. and M. Black. 1994. Seeds: Physiology of development and germination, p. 293-343. Plenum Press, London, UK.

Bewley, J.D., K.J. Bradford, and H.W.M. Hilhorst. 2013. Seeds: Physiology of development, germination, and dormancy. Springer, New York, NY.

Boerjan, W., M. Cervera, M. Delarue, T. Beeckman, W. Dewitte, and C. Bellini. 1995. Super root, a recessive mutation in Arabidopsis confers auxin overproduction. Plant Cell 7:1405-1419.

Bonner, F.T. 2008. Juniperus L., p. 607614. In: F.T. Bonner and R.P Karfalt (eds.). The woody plant seed manual. U.S. Dept. Agr., For. Serv. Hdbk. 727.

Brandel, M. and W. Schutz. 2003. Seasonal dormancy patterns and stratification requirements in seeds of Verbena officinalis L. Basic Appl. Ecol. 44:329-337.

Broome, A. 2003. Growing juniper: Propagation and establishment practices. Information note. Forestry Commission, Edinburgh, UK.

Chauhan, J.S., A. Tomar, N.I. Singh, S. Ali, and A. Debarati. 2009. Effect of growth hormones on seed germination and seedling growth of black gram and horse gram. J. Amer. Sci. 5:79-84.

Chauhan, J.S., Y.K. Tomar, A. Badoni, N.I. Singh, S. Ali, and A. Debarati. 2010. Morphology, germination, and early seedling growth in Phaseolus mungo L. with reference to the influence of various plant growth substances. J. Amer. Sci. 6:34-41.

Daneshvar, A., M. Tigabu, A. Karimidoost, and P.C. Oden. 2016. Stimulation of germination in dormant seeds of Juniperus polycarpos by stratification and hormone treatments. New For. 47:751-761.

Dealy, J.E. 1990. Juniperus occidentalis Hook. Western juniper. Silvics of North America. Conifers. U.S. Dept. Agr., For. Serv., Agr. Hdbk. 654(1):109-115.

Ding, Y. 2004. Effects of several exogenous hormones on germination of leek seeds. Seed Sci. Technol. 5:282-283.
Djavanshir, K. and G.H. Fechner. 1976. Epicotyl and hypocotyl germination of eastern red cedar and rocky mountain juniper. For. Sci. 22:261-266.

Ellis, R.H. and E.H. Roberts. 1981. The quantification of ageing and survival in orthodox seeds. Seed Sci. Technol. 9:373-409.

Fan, L., Z. Linyun, S. Jin'an, and G. Suping. 2012. Promotion of IAA, NAA on seed germination of Jacaranda mimosifolia. J. Agr. Sci. Technol. B2:1184-1189.

Fordham, A.J. and L.J. Spraker. 1977. Propagation manual of selected gymnosperms. Arnoldia 37:1-88.

Gimenez, B., A. Escudero, and F. Perez. 2005. Seed germination of high mountain Mediterranean species: Altitudinal, interpopulation and inter-annual virility. Ecol. Res. 20:433-444.

Harrington, C.A. 1977. Growing conifers from seed. Historical Materials Univ. Nebraska - Lincoln Ext. G77-380:851.

Harris, D., A. Joshi, P.A. Khan, P. Gothkar, and P.S. Sodhi. 1999. On-farm seed priming in semi-arid agriculture: Development and evaluation in maize, rice, and chickpea in India using participatory methods. Exp. Agr. 35:15-29.

Hoque, M. and S. Haque. 2002. Effects of $\mathrm{GA}_{3}$ and its mode of application on morphology and yield parameters of mungbean (Vigna radiata L.). Pakistan J. Biol. Sci. 5:281-283.

International Seed Testing Association. 1999. Proc. 3rd ISTA Seed Health Symp. Ames, IA. 16-19 Aug. 1999. Intl. Seed Testing Assn., Zurich, Switzerland.

Jiang, X.C. and Y.F. Chen. 1997. Effects of soaking by NAA solutions on 'XiangZao-Xian 11' seeds during germination. Seed 6:68-70.

Labbafi, M.R., A. Mehrafarin, H. Naghdi Badi, M. Ghorbani, and M. Tavakoli. 2018. Improve germination of caper (Capparis spinose L.) seed by different induction treatments of seed dormancy breaking. Trakia. J. Sci. 1:70-74.

Leadem, C.L. 1997. Dormancy-unlocking seed secrets, p. 43-52. Natl. Proc., For. Conservation Nursery Assn. Rpt. PNW- G TR-419. U.S. Dept. Agr. For. Serv., P.N.R.S, Portland, OR.

Mazer, S.J. and D.E. Lowry. 2003. Environmental, genetic, and seed mass effects on winged seed production in the heteromorphic Spergularia marina (Caryophyllaceae). Funct. Ecol. 17:637-650.

Muday, G.K. and P. Haworth. 1994. Tomato root growth, gravitropism, and lateral development: Correlation with auxin transport. Plant Physiol. Biochem. 32:193-203.
Nikolaeva, M.G. 1977. Factors controlling seed dormancy pattern, p. 51-74. In: A.A. Khan (ed.). The physiology and biochemistry of seed dormancy and germination. Elsevier/North-Holland Publ., Amsterdam, The Netherlands.

Oliveira, A.K.M., J.W.F. Ribeiro, K.C.L. Pereira, and C.A.A. Silva. 2013. Effects of temperature on the germination of Diptychandra aurantiaca (Fabaceae) seeds. Acta Sci. Agron. 35:203-208.

Penfield, S. 2017. Seed dormancy and germination. Curr. Biol. 27:R853-R878.

Poljak, I., D. Kajba, I. Ljubić, and M. Idžojtić. 2015. Morphological variability of leaves of Sorbus domestica L. in Croatia. Acta Soc. Bot. Pol. 84:249-259.

Schmidt, L. 2000. Dormancy and pretreatment. Extract from "Guide to handling of tropical and subtropical forest seed". Danida For. Seed Ctr., Krogerupvej, Denmark.

Song, P., Q.X. Zhang, H.T. Pan, M. Cai, and X.X. Ren. 2009. Effect of three kinds of plant growth regulators on Lagerstroemia subcostata seed germination. Seed. 28:58-60.

Steel, R.G.D. and J.H. Torrie. 1986. Principle and procedure of statistics. A biometrical approach. 2nd ed. McGraw Hill, New York, NY.

Taiz, L. and E. Zeiger. 2010. Plant physiology. 5th ed. Sinauer Assoc., Sunderland, MA.

Tilki, F. 2007. Preliminary results on the effects of various pre-treatments on seed germination of Juniperus oxycedrus L. Seed Sci. Technol. 35:765-770.

Tylkowski, T. 2009. Improving seed germination and seedling emergence in the Juniperus communis. Dendrobiology 61:47-53.

Tylkowski, T. 2010. Dormancy breaking in savin Juniper (Juniperus sabina L.) seeds. Acta Soc. Bot. Poloniae 79:27-29.

Yao, W.F., Y.B. Shen, and F.H. Shi. 2015. Germination of Tilia miqueliana seeds following cold stratification and pre-treatment with $\mathrm{GA}_{3}$ and magnetically-treated water. Seed Sci. Technol. 43:554-558.

Yavuz, Z. and M. Yilmaz. 2017. Seed dormancy and cone and seed morphology of syrian juniper (Juniperus drupacea Labill.) in the eastern Mediterranean region of Turkey. Sumar. List 5-6:257-262.

Yoshida, I. and E. Hirasawa. 1996. Gibberellin induces endopeptidase activity in detached cotyledons of Pisum sativum. J. Plant Growth Regul. 19:55-60. 